\title{
強風浪下の沖合い流れの 3 次元構造と発生機構
}

\author{
安田孝志* • 加藤 茂 ${ }^{* *} \cdot$ 十二正 義***・山下隆男 $* * * *$
}

\section{1. 緒言}

平均流速が $0.5 \mathrm{~m} / \mathrm{s}$ にも及゙砕波帯沖合いの強い流 れが田中（1994）によって指摘され，これまで数多くの 研究が行われてきた。その結果，発生原因も含めて不明 な点が多かった沖合い流れの実態解明が進み, それが風 による海面せん断力, コリオリ力および砕波を介して波 から供給される運動量に原因した流れであることが明ら かとなってきた（佐藤，1996；安田ら，1996）。

この流れは, 沖合い漂砂を始めとして沿岸域の輸送現 象に広く関わっていると考えられ，広域的に海岸保全や 沿岸域管理を進めて行く上で重要である.しかしながら， このような沖合い流れを海洋学的スケール（傾斜流）あ るいは海岸工学的スケール (海浜流, 海岸流) のいずれ で捉えるかによってそのモデル化は数值モデルまで含め て大きく異なる.このため, 観測結果を基に沖合い流れ の 3 次元構造や外力の変動に対する応答特性を明らかに し, その結果を踏まえてモデル化を進めることは, 長期 的・広域的に安定な海浜の保全を進め, 総合的な沿岸環 境の管理計画を策定する上で必須の課題と言える.

そこで本研究では, 現地データを用いて沖合い流れの 鉛直分布を含めた 3 次元構造と外力である風および波の ベクトル的時間変化に伴う動的応答特性を明らかにする とともに, これを基に, 風, 波およびコリオリ力を考慮 し, 鉛直方向に $\sigma$-座標系を用いた平均流の準 3 次元モデ ルを導き, その適用性を検証する.ついで, このモデル を用いたシミュレーションにより，観測データだけでは 不十分な沖合い流れの特性を明らかにしたい.

\section{2. 観 測 概 要}

ここで用いる波形，流速および風速デー夕は建設省北 陸地建金沢工事事務所によって 1995 年 12 月 28 日から 翌年 1 月 28 日にわたって得られたものであり，その解析 結果も一部既に報告されている(田中ら，1996)。ここで

\footnotetext{
* 正会 員 工博 岐皁大学教授 工学部土木工学科

**学生会員工修岐皁大学大学院 工学研究科

(日本学術振興会特別研究員)

*** 正会員鉄建建設株式会社

**** 正会 員 工博 京都大学助教授 防災研究所
}

は, 石川海岸徳光地先の汀線直角に沖に向かう 3 測点 P 1 (水深 $15 \mathrm{~m}), \mathrm{P} 2(20 \mathrm{~m})$ および P 3 (30 m) での波 形および流速デー夕を解析した．なお， 3 測点間の海浜 勾配はほぼ $1 / 100$ であり, 測点 P 2 および P 3 での流速 は底層 (海底から約 $0.7 \mathrm{~m}$ ) のみであるが, 測点 P 1 では 底層に加えて中層（海底から約 $5.7 \mathrm{~m}$ ) および上層（海底 から約 $10.7 \mathrm{~m})$ の流速も測定されている. 風速デー夕は 徳光地先の陸上観測点におけるものであり, 風向は観測 点における吹き出し方向を示す．各観測データは毎正時 20 分間におけるものであり，これより毎正時の有義波高 $H_{1 / 3}$, 平均スカラー流速 $V$ および風速 $U$ を求めた。

図-1 は，観測期間中の測点 P 1 での $U$ と $H_{1 / 3}$ の経時 変化を示している.この観測期間を主要な暴風期を含む 区間 I, II, IIIおよび静穏期IVに分け, 全区間における 平均流速と気象・海象諸量の関係について調べる.さら に, $V, U, H_{1 / 3}$ を沿岸方向成分 $V_{s}, U_{s}, H_{s}$ (北東向き を正）および岸沖方向成分 $V_{n}, U_{n}, H_{n}$ (岸向きを正)に 分け, これらの岸沖方向変化および測点 P 1 での鉛直分 布についても検討する.

\section{3. 沖合い流れの特性}

\section{1 岸沖変化}

沖合い流れの沿岸方向成分 $V_{s}$ だけでなく岸沖方向成 分 $V_{n}$ の岸沖変化については必ずしも明らかになってお らず，沖合い流れのスケールを明らかにし，その性質を 理解するためにも検討が必要である. 図一 2 は前述の 3

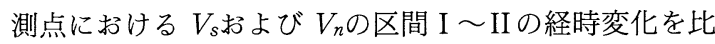
較したものである. 全測点において $V_{s}$ が $V_{n}$ に比べて卓 越しており，沖合い流れの実体は海岸に平行な流れにあ ると言ってよく，特に北東向き（正）の場合に大きく発 達することがわかる.この点では傾斜流と同じであるが, 沖に向かうに従って流速は低下し, 測点 P 3 での $V_{s}$ は



図-1 風速 $U$ と測点 $\mathrm{P} 1$ での $H_{1 / 3}$ の経時変化 


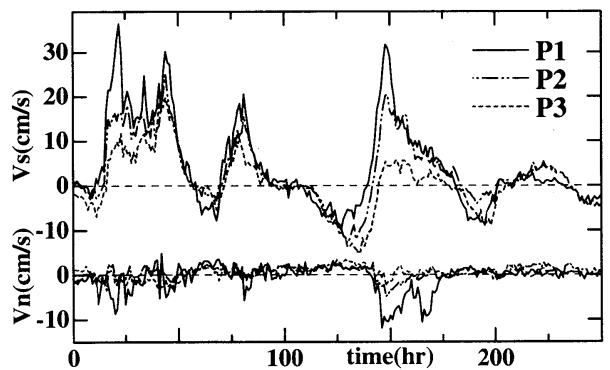

図一2 沖合い流れの沿岸方向成分 $V_{s}$ および岸沖方向成分 $V_{n}$ の経時変化（区間 I - II）の測点間の比較

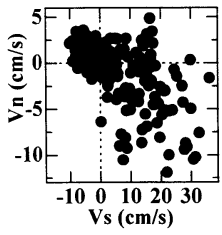

(a) 測点 P 1

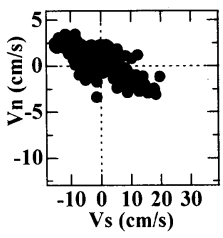

(b) 測点 P 3
図-3 沖合い流れの $V_{s}$ と $V_{n}$ の関係（区間 I - II )

$0.2 \mathrm{~m} / \mathrm{s}$ 以下に留まっている。こうした流速が沖に向か うに従って急減する傾向は $V_{n}$ においてより顕著に現 れ，沖合い流れと言っても傾斜流の上うに海洋学的ス ケールを持つ流れとは異なり，沿岸域に局在した海岸工 学的スケールの流れであると言える.

また， $V_{s}$ と $V_{n}$ の方向変化は 3 測点同時に生じる傾向 がある，すなわち， $V_{s}$ が南西方向 (負) のときは $V_{n}$ は弱 いながら岸向き（正）となっているが， $V_{s}$ が北東（正） に方向を転じて流速を強めると, $V_{n}$ も沖向きに方向を反 転させて流速を増大させている。こうした $V_{s}$ および $V_{n}$ の発達が岸側潮位の上昇による傾斜流の生成と同一の機 構に基づくものとの推察は可能である。しかし，上述し たような沖合い流れの局在性は，この推察に否定的であ る.むしろ，こうした流速の分布特性は沖合い流れを発 達させる推力が沖に向かって単に減少している結果に過 ぎないことを示していると考えるべきであろう。

このような, $V_{s}$ と $V_{n}$ の方向について検討するため, 測点 $\mathrm{P} 1$ および P 3 での区間 $\mathrm{I} \sim \mathrm{II}$ における両者の関係 を図一 3 に示す，沖合い流れが北東向き $\left(V_{s}>0\right)$ に発達 する場合に，同時に沖向き $\left(V_{n}<0\right)$ 流れが発達する傾向 にある。しかし， $V_{n}$ が岸向き（正）のときも北東向きの 沖合い流れ $V_{s}(>0)$ が発生しており, 北東向きの流れを 全て傾斜流とは見なせない場合もある。

\section{2 鉛 直分布}

沖合い流れの鉛直分布は漂砂などの輸送現象に関わっ て重要であるが，流れの発生機構や鉛直混合などを解明 する上でも重要である.

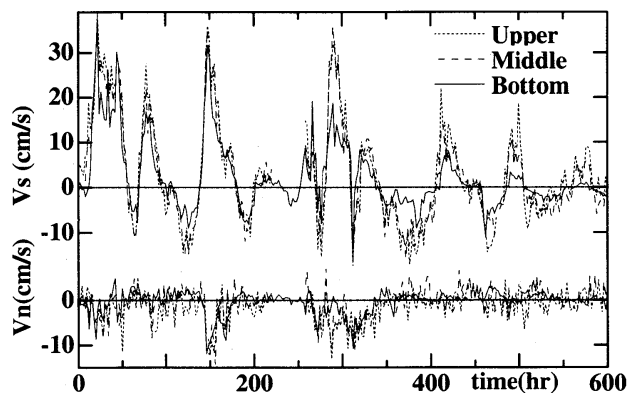

図-4 測点 P 1 での沖合い流れの沿岸方向成分 $V_{s}$ および 岸沖方向成分 $V_{n}$ の鉛直変化（区間 I-II）

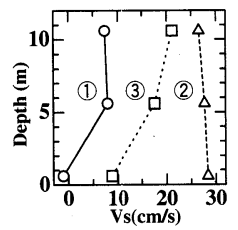

図一5 測点 P 1 での波の(1)発達初期 (10 hr), (2)最発達期 (20 $\mathrm{hr})$ および(3)減衰期 $(50 \mathrm{hr})$ における鉛直分布の比較

图一 4 は測点 $\mathrm{P} 1$ での上中下層の $V_{s}$ および $V_{n}$ の区間 I〜IVにかけての経時変化を示したものである. $V_{n}$ およ び $V_{s}$ 共に鉛直分布の逆転はないものの上中層ほど流速 の絶対值および変動幅が大きい。これは，底面摩擦の影 響にもよるが，沖合い流れの主因が風や波から海面を通 して供給される運動量にあることを示すものと考えられ る．また，発達期には下層でも上層に近い流速が発生す る場合があり，これについては強い鉛直混合を考える必 要がある. 逆に, 沖合い流れが未発達の静穏期 $(450 \sim 600$ hr) においては上中層と下層の差異が大きく,その原因を 鉛直混合の弱さにあると考えることができる。これらの 結果は，沖合い流れを発達させる推力が同時に鉛直混合 の促進に繫がっていることを示すものと言える.

この点をより明確にするため, 波の発達状況と流速の 鉛直分布の関係について検討する. 図一 5 は波の(1)発達 初期，(2)最発達期および(3)減衰期における $V_{s}$ の鉛直分 布を示したものである、砕波の影響が顕著となる最発達 期において流速はほとんど一様になっており，砕波に伴 う鉛直混合によるものと考元られ，事実，砕波の影響 が弱い発達初期扔よび減衰期では下層流速は遅く，せん 断流の分布となっている。こうした鉛直分布の差異は鉛 直混合の強弱により，それは詰まるところ砕波の影響の 程度によっていると考えられる。

\section{3 応答特性}

発達した沖合い流れがコリオリカを主因とする傾斜流 の性格を持つならば，岸向きの風速 $U_{n}(>0)$ および波浪 成分 $H_{n}(>0)$ による岸側潮位の上昇に応じて発達するた 
め, $V_{s}$ の時間変化は $U_{n}$ および $H_{n}$ に対応すると考えら れる. 逆に風や波の直接作用を主因とするなら, $V_{s}$ は $U_{s}$ および $H_{s}$ と対応すると考えられる。

図一6 は，測点 $\mathrm{P} 1$ での $V_{s}, U_{n}$ および $H_{n}$ の区間 $\mathrm{I} に$ おける経時変化を示したものである. 沖合い流れが北東 向きに発達する場合に岸向きの $U_{n}$ および $H_{n}$ の值も増 大している. しかし, これらによって傾斜流が生じる過 程を考えると, $U_{n}$ および $H_{n}$ と $V_{s}$ の間に若干の応答遅

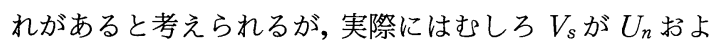
び $H_{n}$ に先行し，事実は矛盾していることになる.

これに対し， $V_{s}$ と $U_{s}$ および $H_{s}$ の関係を示した図一7 を見ると, 時間的変化が互いによく連動し, 時間差は小 さいが風 $\rightarrow$ 波 $\rightarrow$ 流れの順に変化している.特に, $V_{s}$ と $H_{s}$ の間に認められる対応は, 波の作用が沖合い流れの主因 となっていることを強く示唆するものと言える.

こうした沖合い流れの応答特性を相互相関関数 $C$ に よって評価するため, 図一 8 に測点 $\mathrm{P} 1$ の区間 I での $V_{s}$ と $U_{s}, H_{s}, U_{n}, H_{n}$ の各相互相関関数と遅れ時間の関係 を示す．また，図中には各相互相関関数の極大値として 定義される相関係数 $\rho$ の值も示している. この図より, $V_{s}$ は $U_{s}$ に 5 時間, $H_{s}$ に 1 時間遅れて発達・減衰するこ とがわかる，これは，風によって流れと同時に波も発達 するため, 流れと波の発達時間の遅れが小さいことに よっている.また， $H_{s}$ と $V_{s}$ の相関係数の值自体も

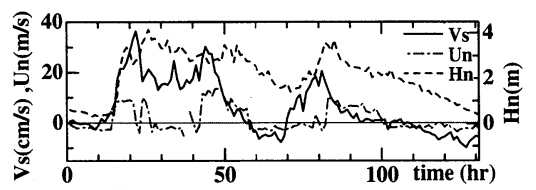

図一6 测点 P 1 での沖合い流れの沿岸方向成分 $V_{s}$ (下層) と 岸側潮位上昇を引き起こす $U_{n}$ および $H_{n}$ の経時変 化の比較

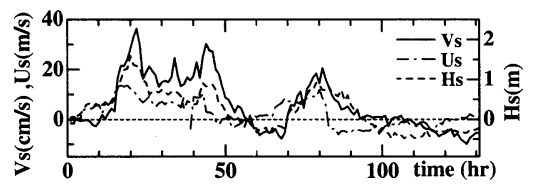

図一7 測点 P 1 での沖合い流れの沿岸方向成分 $V_{s}$ (下層) と その推力となる $U_{s}$ および $H_{s}$ の経時変化の比較

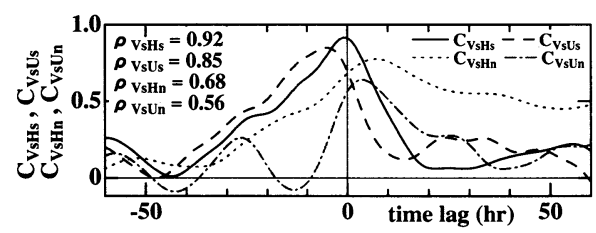

図一8 測点 $\mathrm{P} 1$ での $V_{s}$ (下層) と $H_{s}, U_{s}, H_{n}, U_{n}$ との相 互相関関数
$\rho_{V_{s} H_{s}}=0.92$ となり, $U_{s}$ と $V_{s}$ の相関係数 $\rho_{V_{s} U_{s}}=0.85$ を 上回り，沖合い流れが応答時間も含めて $H_{s}$ と極めて高 い相関を持つことがわかる.これに対し， $V_{s}$ を傾斜流と 捉えた場合，その原因となる $U_{n}$ および $H_{n}$ に $V_{s}$ が先行 し, 因果関係の逆転が生じる.また, 相関係数の值も $\rho_{V_{s} H_{s}}$ や $\rho_{V_{s} U_{s}}$ に比べて $\rho_{V_{s} H_{n}}=0.68$ おょび $\rho_{V_{s} U_{n}}=0.56$ と低 く, 北東向きの発達した沖合い流れを傾斜流と考えるこ とに無理があると言える。

\section{4. 準 3 次元数値計算モデル}

\section{1 基礎方程式}

ここでは, 静水圧近似に基づく準 3 次元モデルを用い る. 海底地形や流速の鉛直分布の重要性を考慮し, 鉛直 方向には $\sigma$-座標系を導入し, 高次の水平拡散項を無視す ると，以下のような連続式および運動方程式を得る。

$$
\begin{aligned}
& \frac{\partial \zeta}{\partial t}+\frac{\partial u D}{\partial x}+\frac{\partial v D}{\partial y}+D \frac{\partial w_{\sigma}}{\partial \sigma}=0 \\
& \frac{\partial u}{\partial t}+u \frac{\partial u}{\partial x}+v \frac{\partial u}{\partial y}+w_{\sigma} \frac{\partial u}{\partial \sigma}-f v \\
& =-\frac{1}{\rho} \frac{\partial p_{a}}{\partial x}-g \frac{\partial \zeta}{\partial x}+\frac{1}{D^{2}} \frac{\partial}{\partial \sigma}\left(N_{\sigma} \frac{\partial u}{\partial \sigma}\right) \\
& +N_{h}\left(\frac{\partial^{2} u}{\partial x^{2}}+\frac{\partial^{2} u}{\partial y^{2}}\right) \\
& \frac{\partial v}{\partial t}+u \frac{\partial v}{\partial x}+v \frac{\partial v}{\partial y}+w_{\sigma} \frac{\partial v}{\partial \sigma}+f u \\
& =-\frac{1}{\rho} \frac{\partial p_{a}}{\partial y}-g \frac{\partial \zeta}{\partial y}+\frac{1}{D^{2}} \frac{\partial}{\partial \sigma}\left(N_{\sigma} \frac{\partial v}{\partial \sigma}\right) \\
& +N_{h}\left(\frac{\partial^{2} v}{\partial x^{2}}+\frac{\partial^{2} v}{\partial y^{2}}\right)
\end{aligned}
$$

ここで, $u, v, w_{\sigma}$ は $x, y, \sigma$ 方向の流速, $\zeta$ は静水面か らの水位, $D=h+\zeta$ は全水深, $h$ は静水深, $f$ はコリオ リ係数, $\rho$ は水の密度, $p_{a}$ は大気圧, $g$ は重力加速度, $N_{\sigma}$ および $N_{h}$ は鉛直および水平方向の渦動粘性係数を示 す. 以上の方程式を空間的にはスタッガード格子を用い て中央差分近似し, 時間発展においてはリープ・フロッ グ法を用いる。

海面および海底境界条件は，それぞれ海面および海底 の摩擦係数を用いて風および流れの摩擦応力で与え, 摩 擦係数はそれぞれ $1.0 \times 10^{-3}$ 抢よび $4.0 \times 10^{-3}$ とした。

\section{2 鉛直渦動粘性係数の推定}

式 ( 2 ) および ( 3 ) における $N_{\sigma}$ は $L_{i} \&$ Zhang (1996) のものに波の影響を加えて, 次式のように仮定する.

$$
N_{\sigma}=\alpha(x, y, t) \Psi(\sigma)+\mu_{\text {tide }}+\mu_{\text {wind }}+\mu_{\text {wave }} \cdots(4)
$$

ここで, $\Psi(\sigma)$ は鉛直方向の分布関数, $\mu_{\mathrm{tide}}, \mu_{\mathrm{wind}}$ 抢よび $\mu_{\mathrm{wave}}$ は潮汐, 風および砕波による渦動粘性係数で, $\mu_{\text {tide }}=2.5 \times 10^{-2}$ とした.また, $\mu_{\text {wind }}=\lambda_{\text {wind }} \times W_{*}$ で, $\lambda_{\text {wind }}$ は有効粗度, $W_{*}$ は風の摩擦速度であり, $\lambda_{\text {wind }}=0.03$ とし 
た.

$\alpha$ は $x, y, t$ 亿依存する係数であり, 次式で表される。 $\alpha(x, y, t)=k_{2}\left(\bar{u}^{2}+\bar{v}^{2}\right)^{1 / 2} \Delta$

ここに, $k_{2}$ は定数, $\bar{u}, \bar{v}$ は鉛直断面の平均流速, $\Delta$ は 海底境界層の厚さを表し, 経験定数 $C(=0.3)$, 海底摩 擦速度 $U_{*}^{B}$, コリオリ係数 $f$ より $\Delta=\left(C U_{*}^{B}\right) / f$ で与えられ る.なお， $f=0$ および $\Delta>h$ の場合には $\Delta=h$ とする.

$\Psi(\sigma)$ に関しては幾つかの分布形が考元られている が,ここでは簡単のために $\Psi=1$ (鉛直方向に一様) とし た.

\section{5. 石川海岸における沖合い流れの計算}

\section{1 計算領域および境界条件}

計算領域として，まず，加佐岬から金沢港までの約 40 $\mathrm{km}$ を想定し, 沿岸方向 $(Y) 40 \mathrm{~km}$, 岸沖方向 $(X) 20$ $\mathrm{km}$ とした。海底地形も現地海岸との対応を考えて $h=$ 5〜50 m の間を $1 / 100$ の一様勾配部とし，それより沖側 は一定水深とした。また, 沿岸方向の境界条件の影響は 大きいため, 岸沖方向の境界条件は, 沖側境界を水深 50 $\mathrm{m}$ の開境界, 岸側境界を水深 $5 \mathrm{~m}$ の固定境界とし, 沿岸 方向の境界条件の違いについて検討を行った。

加佐岬と金沢港を固定境界として沖側境界まで延長さ せた場合，それによる循環流が生じ，その影響が計算領 域内の半分以上にまで及んだ。これは，加佐岬や金沢港 は高々沖合い $2 \mathrm{~km}$ 程度までの障害物に過ぎず，これを 沖合い $20 \mathrm{~km}$ までの固定境界として与えることは過大 評価となることを示している，そこで，石川海岸は越前 岬から能登半島根元までの約 $100 \mathrm{~km}$ に及ぶほほ直線状 の海岸の一部と考え, 沿岸方向に対する束縛が小さい周 期境界を用いることにした。 その結果, 境界条件に原因 する循環流が消えただけでなく, 岸沖方向を $10 \mathrm{~km}$, 沿岸 方向を $20 \mathrm{~km}$ とした場合とも差異は生じなかった。この ため, ここでは計算領域を岸沖方向 $10 \mathrm{~km}$, 沿岸方向 20 $\mathrm{km}$ と設定し, 水平格子サイズを $d x=250 \mathrm{~m}, d y=500 \mathrm{~m}$ の長方形，鉛直方向は 4 層（上層を第 1 層）とした。ま た, 風の場は領域内一様として観測值を全域に与えた。

\section{2 波の影響}

波の影響としては, 主に砕波による流れへの運動量輸 送, 砕波による鉛直混合の促進, ラディエーション応力 による運動量輸送が挙げられる。しかし，砕波の影響に ついては既に著者ら（1995）によって指摘されているが, その定量的評価法が依然として確立されていないため, ここでは，砕波率と波形勾配の関係（安田ら，1995）に 着目して佐藤（1996）によって導入された砕波による表 面応力係数 $C_{w}$ を次式のように修正した。

$$
C_{w}=5.0 \times 10^{-4} \times(H / L)_{1 / 3}
$$

鉛直混合の促進については，前述の式（4）の $\mu_{\mathrm{wave}}$ を $\mu_{\mathrm{wave}}=5.0 \times 10^{-2} \times\left(H_{1 / 3} / h\right)$ のように仮定した.

ラディエーション応力は微小振幅波理論より計算し, 上層においてラディエーション応力が強くなること（信 岡ら，1995）を踏まえ，その水深平均量を第 1 層のみに 考慮することにした．これらの計算で必要となる波の場 は, 沿岸方向に一様とし, 各測点での $H_{1 / 3}, T_{1 / 3}$ および平 均波向 $\theta_{H}$ の観測值を岸沖方向に線形補間して与えた.

\section{3 数値計算結果}

\section{（1）沖合い流れの再現性}

上述の計算モデルの適用性を検証するため, 区間 I に おける各測点での沖合い流れの流速べクトルについて観 測值と計算值の比較を行う。図一9 は, その結果を $H_{1 / 3}$ （測点 P 1）およびUのベクトル的時間変化とともに示し たものである.これから，沖合い流れの岸沖方向の変化 (P 1〜P 3) だけでなく, 測点 P 1 での鉛直方向の変化 (上 中下層）についても計算値は観測值と全体的によく対応 しており, 特に輸送現象として重要な流向の逆転に対し ても十分な再現性を有していることがわかる。ただし， 観測值に現れている細かな流速・流向の変動については 再現性に不十分な点が多く, 外力としての風および波の 影響評価になお問題を残しており, 今後の課題である.

\section{（2）沖合い流れの支配因子}

これまでの観測デー夕に基づく検討によって，沖合い 流れは風および波の沿岸方向成分を推力とした平均流で あることが示されている。ここでは，上述の計算モデル を用いて沖合い流れの支配因子について検討を行う。

図一10 は，波，風およびコリオリ力の各因子をそれぞ れ除いて計算した沖合い流れの沿岸および岸沖方向成分 $V_{s}$ および $V_{n}$ を測点 $\mathrm{P} 1$ の下層での観測值と比較したも のである、ただし，計算値および観測值共に移動平均に よる平滑化を行っている. 全因子を含めて計算した場合, $V_{s}$ のピーク値に差異はあるものの $V_{s}$ および $V_{n}$ 共に時 間的変化の対応は良好である.ついで, 波の作用を除き, 風およびコリオリカのみとした場合を見ると， $V_{s}$ の Time $=60 \sim 70 \mathrm{hr}$ における南西方向への逆転 $\left(V_{s}<0\right)$ が 再現されていないことに加え， $V_{n}$ の流速が小さくなって いる.これに対し，風の作用を除き，波抒よびコリオリ 力のみとした場合では, $V_{s}$ の南西方向への逆転が過大評 価とはなっているものの再現されており，沖合い流れの 方向変化に波の作用が大きな役割を果たしていることが わかる。このように，風の作用を除いた場合， $V_{s}$ が負の 場合のみでなく，正の場合に扔いても計算值が観測值を 上回る結果となり，波の作用だけでは流速の変化が拡大 される傾向にあることがわかる，このことは，風が沖合 い流れを加速させるだけでなく減速もさせ，流速の変動 を緩する役割も果たしていることを示すものと言える. コリオリカの影響を除いた場合では, 計算結果は風の作 


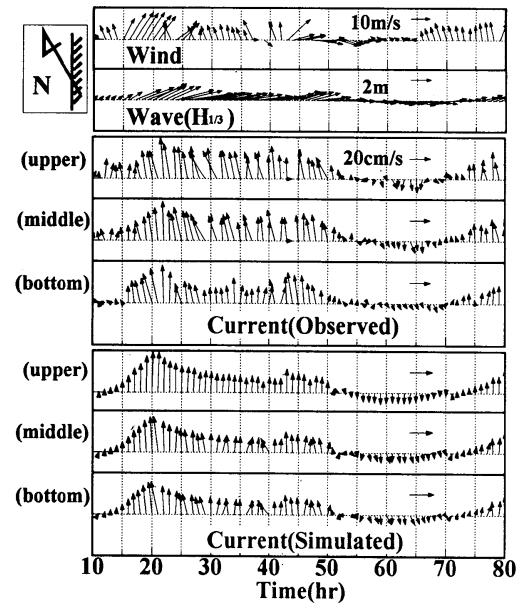

（a）風，波の実測值および流れの鉛直方向変化の比較(測点 P 1)

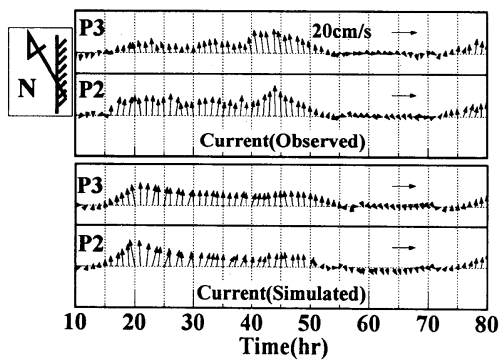

（b）流れの岸沖方向変化の比較（測点 P 2 および P 3)

図一9 実測值と計算值のベクトル的経時変化の比較

用を除いた場合以上に $V_{s}$ に対して過大評価となってい る.しかし，上述の計算モデルではコリオリ係数 $f$ は， $N_{\sigma}$ の值（鉛直混合）にも影響を及ぼし，この結果にはそ の影響も含まれており，コリオリカのみの影響とは言え ない.したがって，コリオリ力は間接的な鉛直混合への 影響も含めて，沖合い流れの沿岸方向成分を減速させる 役割を果たしていることがわかる.

以上より，風扔よび波の作用が沖合い流れの流速・流 向に対する支配因子であり，コリオリ力はその沿岸方向 成分を減速させる役割を果たしていることが明らかと なった。

\section{6. 結 語}

観測デー夕を解析することにより，海岸線に平行に発 達する沖合い流れは，沿岸域に局在した流れであり，風， 波および流れの応答から, 発達した沖合い流れは風およ び波の沿岸方向成分を主因としていることが明らかと なった。また，その鉛直分布は，波の発達状況により異 なり，砕波の影響が顕著となる場合にはほほ一様な分布

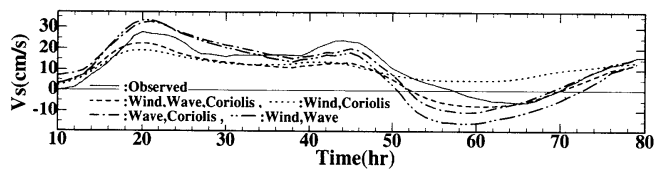

(a) 沿岸方向成分 $V_{s}$

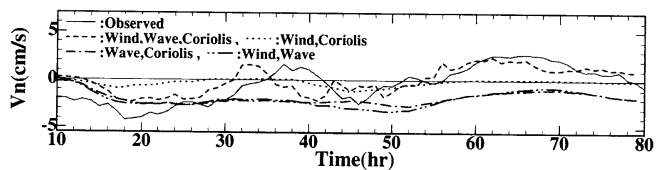

(b) 岸沖方向成分 $V_{n}$

図一10 風，波およびコリオリカの影響の比較

となるのに対し，砕波の影響が弱い場合ではせん断流の 分布となり,砕波の影響の程度により鉛直分布の差異 (鉛 直混合の強弱）が生じることが明らかとなった。

石川海岸を対象とした数值計算においては, 流速・流 向共に全体的によく再現できた。さらに，風・波および コリオリカの各因子の影響について検討した結果, 沖合 い流れを発生させる支配因子は風および波の作用であ り, コリオリカは沿岸方向の流速を減速させる役割を持 つことが明らかとなり, 解析結果を裏付ける計算結果が 得られた。そして，沖合い流れの方向変化には特に波の 作用が重要であることが明らかとなった。

最後に, 厳しい条件下で観測を実施された建設省北陸 地建金沢工事事務所の諸氏に深謝するとともに，観測 データの貸与に当たって格別の御配慮を賜った建設省土 木研究所の佐藤壃司室長に謝意を表す。本研究は文部省 科学研究費による成果であることを付記する.

\section{参 考 文 献}

佐藤㥀司（1996）：強風と高波により発達する沿岸域の大規模流 れに関する研究, 海岸工学論文集, 第 43 巻, pp. 356-360. 田中茂信 (1994)：気になる話，海岸，34-1，pp. 20-27.

信岡尚道 - 加藤 始 - 三村信男 (1996): 海浜鉛直循環流の数值 モデルと特性解析, 海岸工学論文集, 第 43 巻, pp. 376-380. 安田孝志・森 信人・加藤 茂・佐藤買司 (1995)：石川海岸沖 合いの流況特性と砕波の影響について, 海岸工学論文集, 第 42 巻, pp. 431-435.

安田孝志・森 信人・川口浩二・多田彰秀 (1995): 一方向波列 の砕波率とそれを考慮した波高分布の推定法, 海岸工学論文 集, 第 42 巻, pp. 91-95.

安田孝志・加藤 茂・岩田 宏・佐藤買司 (1996)：砕波帯沖合 い流れの特性とその成因について, 海岸工学論文集, 第 43 巻, pp. 366-370.

Li, Y. S. and M. Y. Zhang (1996): A semi-implicit threedimensional hydrodynamic model incorporating the influence of flow-dependent eddy viscosity, bottom topography and wave-current interaction, Applied Ocean Res., 18, pp. 173-185. 